\title{
A MULTI-OBJECTIVE GENETIC ALGORITHM APPROACH TO THE PROBABILISTIC MANUFACTURING CELL FORMATION PROBLEM
}

\author{
V. Jayakumar ${ }^{1 *}$ and R. Raju ${ }^{2}$ \\ ${ }^{1}$ School of Mechanical and Building Sciences \\ VIT University, India \\ jkmails2k2@yahoo.com \\ ${ }^{2}$ Department of Industrial Engineering \\ Anna University, Chennai, India \\ krrajuin@yahoo.co.in
}

\begin{abstract}
Due to customised products, shorter product life-cycles, and unpredictable patterns of demand, manufacturing industries are faced with stochastic production requirements. It is unlikely that the production requirements (product mix and demand) are known exactly at the time of designing the manufacturing cell. However, a set of possible production requirements (scenarios) with certain probabilities are known at the design stage. Though a large number of research works on manufacturing cells have been reported, very few have considered random product mix constraints at the design stage. This paper presents a nonlinear mixed-integer mathematical model for the cell formation problem with the uncertainty of the product mix for a single period. The model incorporates real-life parameters like alternate routing, operation sequence, duplicate machines, uncertain product mix, uncertain product demand, varying batch size, processing time, machine capacity, and various cost factors. A solution methodology for best possible cell formation using a genetic algorithm (GA) is presented, and the computational procedure is illustrated for the case study undertaken.
\end{abstract}

\section{OPSOMMING}

Vanweë doelgemaakte produkte, korter produklewensiklusse en onvoorspelbare vraagpatrone, staar vervaardigingsindustrieë stochastiese produksiebehoeftes in die gesig. Dit is onwaarskynlik dat produksiebehoeftes (produkmengsel en vraag) presies bekend sal wees wanneer die vervaardigingsel ontwerp word. Desnieteenstaande sal ' $n$ stel moontlike produksiebehoeftes (scenarios) met bepaalde waarskynlikhede tog op hierdie stadium bekend wees. Alhoewel heelwat navorsing reeds op vervaardigingselle gedoen is, is daar weinig gerapporteer waar lukraak produkmengselrandvorwaardes by die ontwerpfase oorweeg is. Hierdie artikel hou ' $n$ nie-lineêre gemengde-heeltal- wiskundige model voor vir die selformasieprobleem met onsekerheid oor die produkmengsel in ' $n$ enkelperiode. Die model inkorporeer werklike parameters soos alternatiewe roetes, bewerkingsvolgordes, duplikaat toerusting, onsekere produkmengsels, onsekere produkvraag, wisselende lotgroottes, prosesseertye, toerustingkapasiteit en verskeie kostefaktore. 'n Oplossingsmetodologie aan die hand van ' $n$ genetiese algoritme vir die beste moontlike selformasie word voorgehou en die prosedure word by wyse van ' $n$ gevallestudie geïllustreer.

${ }^{*}$ Corresponding author. 


\section{INTRODUCTION}

Cellular manufacturing (CM) is an application of group technology in which dissimilar machines have been aggregated into cells, each of which is dedicated to the production of a part family. The primary advantage of $C M$ implementation is that a large manufacturing system can be decomposed into smaller subsystems of machines called cells. These cells are dedicated to processing part families based on similarities in manufacturing requirements. $\mathrm{CM}$ is a hybrid system linking the advantages of job shops (flexibility in producing a wide variety of products) and flow lines (efficient flow and high production rate). Parts with similar manufacturing requirements can be processed entirely in that cell. The potential benefits associated with the application of $\mathrm{CM}$ include improved market response, more reliable delivery promises, reduced tooling and fixtures, higher machine use, shorter throughput time, reduced work-in-process, reduced materials handling, improved product quality, and simplified production planning and control (Wemmerlov and Johnson [1]). In addition, cells represent sociological units conducive to team work (Huber and Hyer [2]), leading to higher levels of motivation for process improvements. It can be argued that, the more complex the product, the more can benefits be realised through the application of CM. Dale [3] discovered that the greater the complexity of the product, the greater are the benefits of $\mathrm{CM}$. His survey also revealed that component variety is much more important for the success of $\mathrm{CM}$ than factors such as the number and types of machine tools, and the number of batches.

The central issue in the design of cellular manufacturing systems (CMSs) is the formation of part families and machine cells. In recent decades many researchers have extensively studied the cell formation problem in CMS design. Different models have been proposed to achieve better cell formation. Comprehensive summaries and taxonomies of studies devoted to cell formation can be found in Wemmerlov \& Hyer [4], Kusiak [5], Singh [6], Reisman et al. [7], Selim et al. [8], Sarker \& Mondal [9], and Mansouri et al. [10]. Most of the design approaches for CMSs proposed over the years still have one or more of the following limitations: (i) Most of the suggested models consider binary machine-part incidence matrices. On the other hand, solving real-life problems involves the use of a range of production-related information (such as operation sequence of parts, production volume, set-up and processing times, machine capacity, machine availability, and material handling capacity). (ii) It is observed that the vast majority of studies in the area of cell formation have employed small-sized problems that are hypothetical and produce only theoretical studies. There is a growing need to develop specific solution procedures that are capable of handling large-sized real-life problems. (iii) Although many research approaches promise potential applications, the research does not carry over into practice. (iv) Most of the suggested cell design models considered a single-objective function; but the real life CMS design problems require a multi-objective function. There is a growing need for and interest in developing integrated models that address several pragmatic production issues simultaneously in the design of a CMS. (v) Very few works have considered incorporating uncertainty in production requirements into the CMS design during the design stage.

Though a lot of research into manufacturing cells has been reported, very little has considered the random product mix constraint at the design stage. However, the design of CMS under stochastic production requirements has received attention in recent years (Seifoddini [11], Sankaran \& Kasilingam [12], Harhalakis et al. [13], Chen [14], Wicks \& Reasor [15], Mungwatanna [16], Schaller [17]). Seifoddini [11] developed a single-objective machine cell formation model incorporating the probabilistic nature of the product mix and the associated machine-component chart for a single period. He suggested alternative machine cell arrangements (one for each product mix) and determined their inter-cellular material handling costs under all possible product mixes. Based on the calculated expected inter-cellular material handling cost for each machine cell arrangement, a near-optimal solution is selected. His algorithm has the drawback of considering only the optimal designs of each product mix to calculate the expected inter-cell material handling cost. Sankaran \& Kasilingam [12] presented a mixed integer programming model for different-sized cells 
within a single layout for a single period. They considered three cost scenarios in their problem sets, and proposed a heuristic procedure to solve the model. Harhalakis et al. [13] developed a two-stage design approach to obtain a robust CMS design that is effective over the ranges of expected demand over multiple periods. They divided a system design horizon into elementary time periods. According to their work, the designed cell configuration is expected to remain unchanged over the entire multi-period horizon. In the first stage, the production volume for each product is determined; and in the second stage, a near-optimal cell formation is obtained using a heuristic method. Mungwatanna [16] presented a CMS model for dynamic and deterministic production requirements with the presence of routing flexibility. He solved the model using CPLEX software, without which large-size problems cannot be solved. He then extended his model to the dynamic and stochastic cell design problem, and also proposed a heuristic to solve it. Chen \& Cao [18] proposed an integrated model for production planning in a CMS that minimises the inter-cell material handling cost, the fixed charge cost of setting up manufacturing cells, the cost of holding finished items over the planning horizon, the cost of setting up the system to process different parts in different time periods, and the machine operating cost. loannou [19] developed a comprehensive method for transforming purely functional manufacturing shops into hybrid production systems that have both cellular and functional areas. Schaller [17] proposed an integer model that considers part reallocation or equipment reallocation between cells as an alternative to the design of a cellular manufacturing system to handle long-term demand changes. He employed a problem-specific heuristic called the CB procedure, and the tabu search procedure, to obtain the accepted solution. However, parameters like the inter- and intra-cell movement of parts, the operational sequence, and batch size are not considered in the model.

This paper presents a solution for the cell formation problem with the uncertainty of the product mix for a single period. The description of the problem and the development of a non-linear programming model are presented in the next section. The use of a genetic algorithm to solve the problem is discussed in section 3. A case study is presented to illustrate the applicability of the proposed model and the solution technique. The computational experience is described in section 4 , and conclusions are presented in section 5 .

\section{PROBLEM DESCRIPTION AND MODEL DEVELOPMENT}

This section covers the development of a multi-criteria non-linear mixed-integer mathematical model for the cell formation problem with the uncertainty of the product mix for a single period. The model incorporates real-life parameters like alternate routing, operation sequence, duplicate machines, uncertain product mix, uncertain product demand, batch size, processing time, machine capacity, and various cost factors. This model is based on the framework initially developed by Mungwatanna [16] and TavakkoliMoghaddam et al. [20]. The objective of the proposed model is to minimise the sum of the machine constant cost, the operating cost, the inter-cell material handling cost, and the intra-cell material handling cost for the given period.

\subsection{Assumptions}

The following assumptions are made for the development of the model:

1. There is a finite number of possible product mixes (scenarios) that can occur.

2. Each product is represented by a unique set of part types and their associated demands.

3. Each product mix has a known probability of occurrence.

4. Operating times for all part type operations on different machine types are known.

5. The capabilities and capacity of each machine type are known.

6. Parts are moved between and within cells in batches. Inter- and intra-cell batches have different costs and sizes. The unit intra- and inter-cell material handling costs are constant for all moves, regardless of the distance travelled.

7. The number of cells used must be specified in advance. Upper and lower bounds and the quantity of machines in each cell need to be specified in advance. 
8. Each machine type can perform one or more operations (machine flexibility). Likewise, each operation can be done on one machine type with different times (routing flexibility).

\subsection{Notation used}

The following notations are used in the model:

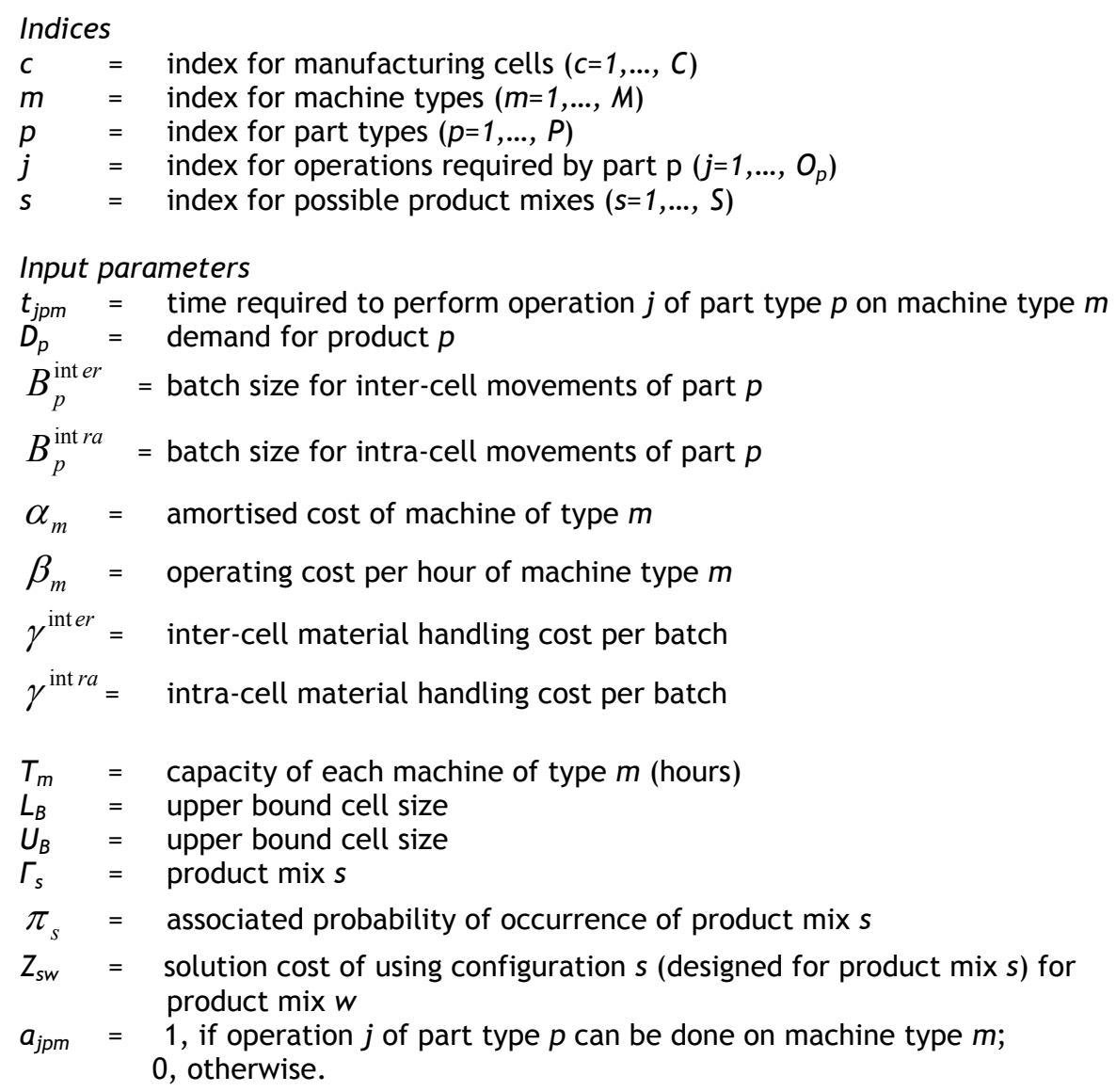

Decision variables

$N_{m c}^{s}=$ number of machines of type $m$ used in cell $c$ for product mix $s$

$x_{j p m c}^{s}=1$, if operation $j$ of part type $p$ is done on machine type $m$ in cell $c$ for product mix $s ; 0$, otherwise.

\subsection{Mathematical formulation}

Using the above notation, the mathematical model for the CMS design for a particular product mix that forms part families and machine groups simultaneously is presented below. 
Minimise:

$$
\begin{aligned}
& Z=\sum_{c=1}^{C} \sum_{m=1}^{M} N_{m c}^{s} \alpha_{m}+\sum_{c=1}^{C} \sum_{m=1}^{M} \sum_{p=1}^{P} \sum_{j=1}^{O_{p}} D_{p} t_{j p m} x_{j p m c}^{s} \beta_{m} \\
& +\frac{1}{2} \sum_{p=1}^{P} \sum_{j=1}^{O_{p}-1} \sum_{c=1}^{C}\left[\frac{D_{p}}{B_{p}^{\text {int } e r}}\right] \gamma^{\text {inter }}\left|\sum_{m=1}^{M} x_{(j+1) p m c}^{s}-x_{j p m c}^{s}\right| \\
& +\frac{1}{2} \sum_{p=1}^{P} \sum_{j=1}^{O_{p}-1} \sum_{c=1}^{C}\left|\frac{D_{p}}{B_{p}^{\text {int } r a}}\right| \gamma^{\text {int } r a} \\
& \left(\sum_{m=1}^{M}\left|x_{(j+1) p m c}^{s}-x_{j p m c}^{s}\right|-\left|\sum_{m=1}^{M} x_{(j+1) p c}^{s}-\sum_{m=1}^{M} x_{j p c}^{s}\right|\right)
\end{aligned}
$$

Subject to:

$$
\begin{array}{lc}
\sum_{c=1}^{C} \sum_{m=1}^{M} a_{j p m} x_{j p m c}^{s}=1 & \forall j, p \\
\sum_{p=1}^{P} \sum_{j=1}^{O_{p}} D_{p}^{s} t_{j p m} x_{j p m c}^{s} \leq T_{m} N_{m c}^{s} & \forall m, c \\
\sum_{m=1}^{M} N_{m c}^{s} \geq L B & \forall c \\
\sum_{m=1}^{M} N_{m c}^{s} \leq U B & \forall c \\
x_{j p m c}^{s} \in\{0,1\} ; & N_{m c}^{s} \geq 0 \& \text { integer }
\end{array}
$$

The non-linear integer objective function given in Eq. (1) minimises the total of the machine constant (investment) cost, the operating cost, the inter-cell material handling cost, and the intra-cell material handling cost for a particular product mix. The first term represents the machine investment cost, which is obtained by summing the products of the number of machines of each type and their respective costs. Though this term does not allow for the extra machine duplication, it leads to effective machine use. The second term is the cost of the operating machines, which is the sum of the products of the number of hours of each machine type and their respective costs. This term ensures a balance between the workload assigned to machines in each cell. The third term is the inter-cell material handling cost, which is obtained by summing the products of the number of intercell transfers for each part type and the cost of transferring an inter-cell batch of each part type. The last term is the intra-cell material handling cost, which is obtained by summing the products of the number of intra-cell transfers for each part type and the cost of transferring an intra-cell batch. Equation (2) ensures that each part operation is assigned to one machine and one cell. Equation (3) ensures that machine capacities are not exceeded and can satisfy the demand. This equation also determines the required number of each machine type in each cell, including machine duplication. Equations (4) and (5) specify the lower and upper bounds of cells.

\section{SOLUTION METHODOLOGY}

Since the cell formation problem belongs to the category of NP-hard problems, the use of meta-heuristic algorithms such as genetic algorithm, simulated annealing, neural networks, and tabu search is unavoidable. A genetic algorithm for solving the proposed model is presented in this section. A genetic algorithm has been effectively used by many authors to 
solve the machine-cell formation problem (Venugopal \& Narendaran [21], Gupta et al. [22], Hu et al. [23], Onwubolu \& Mutingi [24], Suer et al. [25], Tariq et al. [26]).

\subsection{Genetic algorithm}

Genetic algorithms (GAs) were introduced by Holland [27], and have been applied in a number of fields including mathematics, engineering, biology, and social science (Goldberg [28]). GAs are search algorithms based on the mechanics of natural selection and natural genetics. They combine the concept of survival of the fittest with structured yet randomised information exchange to form robust search algorithms.

A GA is based on an analogy with the phenomenon of natural selection in biology. First, a chromosome structure is defined to represent the solutions of the problem. GAs can be implemented in a variety of ways. Using this structure, an initial solution population is generated, either randomly or using a given heuristic. Then members of the population are selected, based on an evaluation function called 'fitness' that associates a value with each member according to its objective function. The higher a member's fitness value, the more likely it is to be selected. Thus the less fit individuals are replaced by those who perform better. Genetic operators are then applied to the selected members to generate a new population. This process is repeated until a certain number of iterations are reached.

The main components of a GA for implementation identify six components:

1. The scheme for coding.

2. The initial population.

3. An adaptation function for evaluating the fitness of each member of the population.

4. A selection procedure.

5. The genetic operators used to produce a new generation.

6. Certain control parameter values (e.g. population size, number of iterations, genetic operator probabilities).

\subsection{Components of the proposed genetic algorithm}

\section{The scheme for coding}

The first step is to determine the solution representation schema. The solution representation presented by Tavakkoli et al. [29] in the matrix form is used in this work to solve the single-period cell formation problem. Two matrices $[X]_{R \times P}$ and $[Y]_{R \times P}$ are used to represent a solution, as shown in Figure 1 , where $R=\max _{p}\left\{O_{p}\right\}$. The matrix $[X]$ represents the assignment of part operation to machine, and the matrix $[Y]$ represents the assignment of part operation to cell. $x_{j p}$ is the machine that operation $j$ of part $p$ must be performed on, where $x_{j p} \in \Psi_{j p}=\left\{m \mid a_{j p m}=1\right\}$. Also $y_{j p}$ is the cell to which operation $j$ of part $p$ is allocated, where $1 \leq y_{j p} \leq C$. Because of $O_{p} \leq R \forall p$, some of the entries in the solution representation are inherently zero.

$$
\left|\begin{array}{cccc}
X_{11} & X_{12} & \ldots & X_{1 P} \\
X_{21} & X_{22} & \ldots & X_{2 P} \\
\ldots & & & \\
X_{R 1} & X_{R 2} & \ldots & X_{R P}
\end{array}\right| \begin{array}{llll}
Y_{11} & Y_{12} & \ldots & Y_{1 P} \\
Y_{21} & Y_{22} & \ldots & Y_{2 P} \\
\ldots & & & \\
Y_{R 1} & Y_{R 2} & \ldots & Y_{R P}
\end{array} \mid=\left\lfloor[X]_{R \times P} \mid[Y]_{R \times P}\right\rfloor
$$

Figure 1: Chromosome microscopic structure

\section{The initial population generation}

The initial population is generated by constructing the $[X]$ and $[Y]$ matrices randomly using a sequential strategy. First, lower bound machines are assigned to each cell randomly. Then 
the operations related to each part type are assigned randomly to machines existing in cells using the $a_{j p m}$ values. As required, the new machines are assigned to cells or relocated among them. If possible, each operation should be assigned to the cell to which the previous operation was assigned.

\section{Fitness function}

The purpose of the fitness function is to measure how good the candidate solutions in the population are in relation to the objective and constraint functions of the model. In this work, the fitness function is the same objective function presented in the mathematical model. The new solution is accepted when its objective function value is lower than its parents' value.

\section{Selection procedure}

The goal of selection is to allow the 'fittest' individuals to be considered more often in order to reproduce children for the next generation. Each individual is assigned a probability of being selected, based on its fitness value. Although better individuals will have a higher probability of being selected to reproduce the next generation, all individuals in the population will have a chance to be selected. There are many methods to select the chromosomes, each with its advantages and disadvantages. In this work, a normalised fitness strategy is used. According to this strategy, the fitness of current generation chromosomes are first normalised, and then the chromosomes whose normalised fitness is less than or equal to zero are selected as a mating pool.

\section{GA operators}

The GA operators are used to produce a new population generation. Since the chromosome structure is in a matrix form, the GA linear operators cannot be used in the traditional way. However, the objectives of three operators - cross-over, mutation, and inversion - are achieved by considering three cases: columnar, linear, and restricted. In each iteration, one of the operations is carried out randomly over one of the matrices $[X]$ or $[Y]$ related to the current chromosome.

(i) Inversion operator in horizontal direction: In this case, two numbers are first selected randomly in either $[\mathrm{X}]$ or $[\mathrm{Y}]$ matrix row limits, then the inversion operator in a horizontal direction is exercised over the columns obtained (Figure 2).

$\left|\begin{array}{l|l|l|l|l}8 & 7 & 2 & 1 & 0 \\ 5 & 3 & 2 & 6 & 5 \\ 2 & 0 & 5 & 3 & 4 \\ 3 & 5 & 4 & 0 & 1 \\ 3 & 1 & 5 & 0 & 0 \\ 6 & 4 & 2 & 1 & 3\end{array}\right| \longrightarrow\left|\begin{array}{ll|l|l|l|}8 & 7 & 2 & 1 & 0 \\ 5 & 3 & 2 & 6 & 5 \\ 2 & 0 & 5 & 3 & 4 \\ 3 & 5 & 4 & 0 & 1 \\ 0 & 0 & 5 & 1 & 3 \\ 6 & 4 & 2 & 1 & 3\end{array}\right| \longrightarrow$

Figure 2: Inversion operation as columnar

(ii) Inversion operator in vertical direction: In this case, two numbers are first selected randomly in either $[\mathrm{X}]$ or $[\mathrm{Y}]$ matrix columnar limits, then the inversion operator in a vertical direction is exercised over the rows obtained (Figure 3 ). 


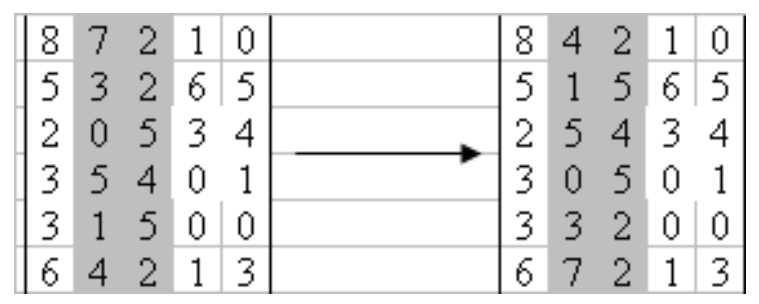

Figure 3: Inversion operation as linear

(iii) Crossover operator as block: In this case, the blocks are selected randomly from two selected chromosomes, and then the crossover operator is carried out to produce two new offspring (Figure 4).

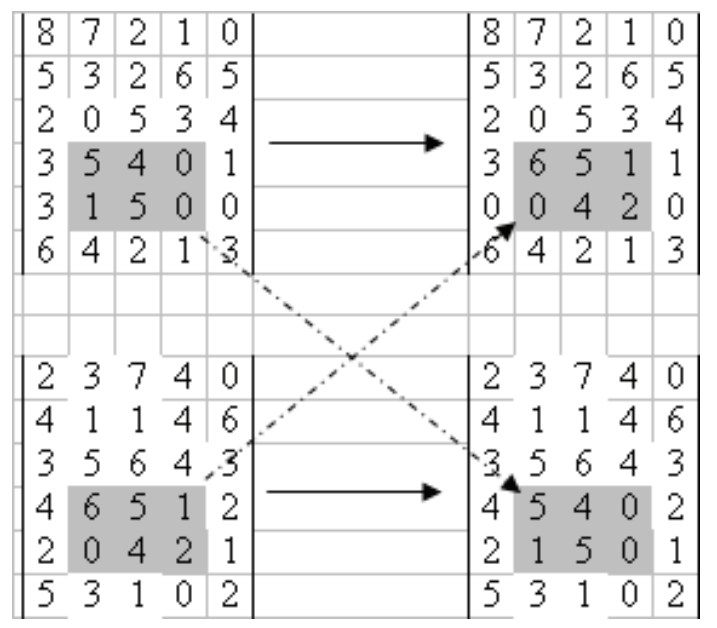

Figure 4: Crossover operator as block

After the implementation of each operator, the value of the decision variable $N_{m c}^{s}$ should be updated based on the entries in $[X]$ and $[Y]$ matrices, using the relation given below.

$$
N_{m c}^{s}=\left[\frac{\sum_{x_{j p}^{s}=m, y_{j p}^{s}=c} D_{p} t_{j p m}}{T_{m}}\right]
$$

\section{Stopping criterion}

The maximum number of generations $(N)$ is used as a stopping criterion. Thus the algorithm is stopped if the number of generations exceeds $N$.

\section{CASE STUDY AND COMPUTATIONAL RESULTS}

In this section, a case study problem is presented to illustrate the applicability of the proposed model in a stochastic environment for single-period planning. The proposed algorithm is coded using $\mathrm{C}++$ programming language, and the experiments are run on a Pentium $42.40 \mathrm{GHz}$ personal computer with $512 \mathrm{MB}$ RAM. A consultancy is carried out for the proposed auto-components manufacturing industry to be located in the suburb of Chennai, Tamil Nadu, India. A reputable auto-components manufacturing industry, which is a batch production industry located in Ambattur Industrial Estate, Chennai (considered the hub of the Indian automobile industry) is a leading supplier of sub-assemblies to many 
automobile companies, including Lucas TVS Ltd, Brakes India Ltd, and Eicher Ltd. This industry manufactures a variety of auto-components such as assemblers ( $P \& \mathrm{~V}$ assembly and flywheel assembly), ball valve parts, distribution parts (shafts), starter motor parts (drive parts, core swifter), brake components (calibre piston, plunger adjuster), fuel injection pump parts (piston, barrel) and transmission parts (gears, shafts, and flywheels). To meet the varying demands, the company has decided to expand its production capacity at another location in Chennai. It has submitted a proposal to start a new industry using the cellular layout. Our task is to design the CMS for a new firm, for which product mix and demand are not known precisely at this design stage. However, from past experience and the demand forecasts, three possible product mixes (scenarios) and their associated demands are mapped. The data set is shown in Table 1. Three possible product mixes are likely to be produced with the probabilities of $0.4,0.3$, and 0.3 respectively in the first planning period. In the first product mix, fifteen part types $(1,2,4,5,6,8,10,11,12,13$, $14,18,19,20$ and 21) are produced. The second product mix consists of sixteen part types $(1,2,3,6,7,8,10,11,13,14,15,17,19,21$, and 22). Similarly, the third product mix consists of fourteen part types $(2,3,4,5,8,9,11,12,13,16,17,18,20$, and 22).

\begin{tabular}{|c|c|c|c|}
\hline \multirow{2}{*}{$\begin{array}{c}\text { Part type, } \\
p\end{array}$} & Demand, $\boldsymbol{D}_{p}$ & \\
\cline { 2 - 4 } & Scenario $1, \Gamma_{1}$ & Scenario $2, \Gamma_{2}$ & Scenario $3, \Gamma_{3}$ \\
\hline 2 & 3000 & 2000 & 0 \\
2 & 7500 & 3500 & 5000 \\
3 & 0 & 1350 & 1800 \\
4 & 2750 & 0 & 1600 \\
5 & 8550 & 0 & 3000 \\
6 & 900 & 1750 & 0 \\
7 & 0 & 2500 & 0 \\
8 & 12000 & 5000 & 7500 \\
9 & 0 & 0 & 2250 \\
10 & 4000 & 2750 & 0 \\
11 & 1250 & 750 & 3000 \\
12 & 3600 & 0 & 1750 \\
13 & 8000 & 4500 & 7500 \\
14 & 11500 & 8500 & 0 \\
15 & 0 & 2250 & 0 \\
16 & 0 & 0 & 1400 \\
17 & 0 & 6000 & 3500 \\
18 & 6000 & 0 & 4500 \\
19 & 750 & 1000 & 0 \\
20 & 5000 & 0 & 2000 \\
21 & 1450 & 2750 & 0 \\
22 & 0 & 1250 & 3000 \\
\hline
\end{tabular}

Table 1: Product mixes and their demands

The part type attributes, such as the number of operations, operation sequence, processing times, inter-cell batch size, and intra-cell batch size, are shown in Table 2. Part 2 requires four operations to be completed: operation 1 is performed in M12, operation 2 can be performed either in M16 having machining time 0.85 minutes or M8 having machining time 0.41 minutes; operation 3 is done in $M 4$; and operation 4 can be done either in $M 2$ having machining time 0.32 minutes or $M 8$ having machining time 0.48 minutes. This provides the routing flexibility. 


\begin{tabular}{|c|c|c|c|c|c|}
\hline 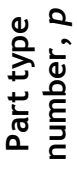 & 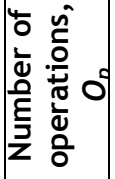 & 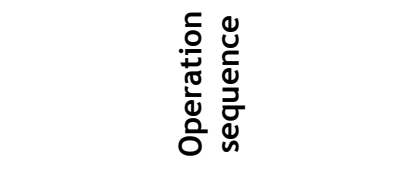 & 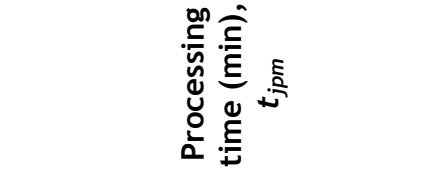 & 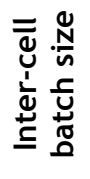 & 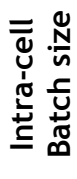 \\
\hline P1 & 5 & M10-M7-M14-M11-M13 & $0.81-0.72-1.20-0.54-0.50$ & 125 & 25 \\
\hline P2 & 4 & $M 12-M 16 / M 8-M 4-M 2 / M 8$ & $0.65-0.85 / 0.41-0.63-0.32 / 0.48$ & 100 & 20 \\
\hline P3 & 4 & M4-M9/M3-M6-M15 & $0.32-0.41 / 0.64-0.86-1.10$ & 150 & 30 \\
\hline P4 & 3 & $M 2-M 5 / M 12-M 10$ & $0.95-0.65 / 0.45-0.80$ & 150 & 30 \\
\hline P5 & 5 & M9-M3-M6-M10-M15 & $0.22-0.84-1.50-0.74-.62$ & 200 & 40 \\
\hline P6 & 7 & M5-M8-M16-M14-M11-M2-M6 & $0.88-0.42-0.45-0.72-0.60-1.15-$ & 150 & 30 \\
\hline P7 & 4 & M6-M3-M1-M14 & 0.70 & 250 & 50 \\
\hline P8 & 3 & $M 2-M 4 / M 12-M 14$ & $1.30-0.65-0.55-0.80$ & 225 & 45 \\
\hline P9 & 4 & M10-M15-M8-M3 & $0.80-0.55 / 0.70-0.90$ & 200 & 40 \\
\hline P10 & 5 & $M 6-M 10-M 5-M 12-M 3$ & $0.75-0.62-0.45-0.35$ & 225 & 45 \\
\hline P11 & 3 & $M 2-M 12 / M 4-M 8 / M 15$ & $0.22-0.78-0.57-0.32-0.95$ & 150 & 30 \\
\hline P12 & 4 & M7-M11-M9-M6 & $1.15-0.68 / 0.45-0.94 / 0.72$ & 175 & 35 \\
\hline P13 & 3 & M12-M2/M6-M15 & $0.36-1.40-1.15-0.74$ & 125 & 25 \\
\hline P14 & 6 & M4-M9-M7-M14-M11-M12 & $0.95-0.45 / 0.65-0.78$ & 200 & 40 \\
\hline P15 & 3 & M5-M11-M7 & $0.64-0.76-0.82-0.45-0.58-0.95$ & 150 & 30 \\
\hline P16 & 4 & M16-M14-M12-M8/M2 & $0.55-1.58-0.78$ & 125 & 25 \\
\hline P17 & 3 & M5-M1/M9-M13 & $0.68-0.42-0.74-0.36 / 0.64$ & 125 & 25 \\
\hline P18 & 3 & M5-M9-M16 & $0.52-0.78 / 1.15-1.26$ & 150 & 30 \\
\hline P19 & 4 & M8-M11/M1-M3-M6 & $1.76-0.72-0.64$ & 100 & 20 \\
\hline P20 & 6 & M7-M9-M4-M5-M8-M12 & $0.65-0.45 / 0.70-1.42-1.16$ & 225 & 45 \\
\hline P21 & 3 & M14-M7/M3-M11 & $0.95-0.36-0.42-0.66-0.90-0.54$ & 200 & 40 \\
\hline P22 & 4 & M13-M8-M5-M3 & $\begin{array}{l}0.88-0.72 / 0.58-1.10 \\
0.75-0.50-0.35-0.94\end{array}$ & 150 & 30 \\
\hline
\end{tabular}

Table 2: Part type attributes

Sixteen machine types are required to produce these part types. The machine types that are used include hydraulic presses, mechanical presses, CNC lathes, vertical machining centres, horizontal machining centres, cylindrical grinders, CNC angular grinders, angular CYL grinders, drilling machines, centre lathes, surface grinding machines, tapping machines, thread rolling machines, sealed quench furnaces, annealing furnaces, and tempering furnaces. Purchase and operating costs are machine-specific. The resource data for the different machines used are given in Table 3. Assuming that a machine operates for eight hours a day and five days a week for 50 weeks a year, the machine capacity is taken to be 2,000 hours. The inter- and intra-cell material handling costs per batch are taken to be $\$ 30\left(\gamma^{\text {inter }}\right)$ and $\$ 6\left(\gamma^{\text {intra }}\right)$ respectively. Due to the non-availability of some production data, some of the input parameters are taken from the literature (Chen [14], Wicks \& Reasor [15]).

This case study has been solved using the proposed genetic algorithm. The GA parameters used in running the program are: number of populations used in each generation, $K=150$; and maximum number of generations (stopping criterion), $N=100$. The problem is solved independently for each product mix, and the cell configurations are obtained correspondingly. For each cell configuration, the total cost - consisting of machine constant cost, operating cost, and inter- and intra-cell movement costs - is calculated for different product mixes. The solutions obtained for each product mix are shown in Table 4. Seifoddini [11] has chosen a cell configuration that has the lowest expected cost. In order to determine the expected cost, a payoff matrix for different cell configurations is obtained (Table 5). From the pay-off matrix, it may be noted that, if cell configuration 1 is used for product mix 2 (product mix 3 ), then the cell configuration cost is $\$ 199,229(\$ 195,592)$. If cell configuration 2 is used for product mix 1 (product mix 3 ), then the cell configuration 
cost is $\$ 210,419(\$ 196,828)$. Similarly, if cell configuration 3 is used for product mix 1 (product mix 2 ), then the cell configuration cost is $\$ 212,887(\$ 189,326)$. It is obvious that, if cell configuration 1 is used for product mix 2 (product mix 3), the solution cost will be higher than $\$ 180,651(\$ 192,392)$; similarly, if cell configuration 2 is used for product mix 1 (product mix 3), the solution cost will be higher than $\$ 207,222(\$ 192,392)$.

For each cell configuration, the total expected cost is calculated as follows:

$$
\begin{aligned}
& E\left[Z_{1}\right]=0.4 \times 207,222+0.3 \times 199,229+0.3 \times 195,592=\$ 201,335 \\
& E\left[Z_{2}\right]=0.4 \times 210,419+0.3 \times 180,651+0.3 \times 196,828=\$ 197,411 \\
& E\left[Z_{3}\right]=0.4 \times 212,887+0.3 \times 189,326+0.3 \times 192,392=\$ 199,670
\end{aligned}
$$

From the above, the cell configuration for the second product mix results in the lowest total expected cost. Therefore, according to Seifoddini's work, the cell configuration for the second product mix is selected for the design of the manufacturing system. It is possible that there is a system design with a lower total expected cost over all product mixes; but it may not be optimal for any individual product mix.

\begin{tabular}{|c|c|c|c|}
\hline $\begin{array}{c}\text { Machine } \\
\text { type } \\
\text { number, } \boldsymbol{m}\end{array}$ & $\begin{array}{c}\text { Investment } \\
\text { cost } \mathbf{( \$ )}, \alpha_{m}\end{array}$ & $\begin{array}{c}\text { Operating } \\
\text { cost } \\
\text { (\$/hr), } \beta_{m}\end{array}$ & $\begin{array}{c}\text { Machine } \\
\text { capacity } \\
\text { (hr/year), } \boldsymbol{T}_{\boldsymbol{m}}\end{array}$ \\
\hline M1 & 3250 & 35 & 2000 \\
M2 & 4500 & 40 & 2000 \\
M3 & 3500 & 25 & 2000 \\
M4 & 3000 & 30 & 2000 \\
M5 & 1800 & 20 & 2000 \\
M6 & 1800 & 20 & 2000 \\
M7 & 2750 & 25 & 2000 \\
M8 & 2500 & 25 & 2000 \\
M9 & 3750 & 35 & 2000 \\
M10 & 5000 & 45 & 2000 \\
M11 & 7500 & 50 & 2000 \\
M12 & 1500 & 20 & 2000 \\
M13 & 3250 & 30 & 2000 \\
M14 & 3750 & 35 & 2000 \\
M15 & 3000 & 25 & 2000 \\
M16 & 2500 & 25 & 2000 \\
\hline
\end{tabular}

Table 3: Machine type attributes

\begin{tabular}{|c|c|c|c|c|c|}
\hline $\begin{array}{c}\text { Product } \\
\text { mix, } \mathbf{s}\end{array}$ & $\begin{array}{c}\text { Machine } \\
\text { constant } \\
\text { cost (\$) }\end{array}$ & $\begin{array}{c}\text { Operating } \\
\text { cost (\$) }\end{array}$ & $\begin{array}{c}\text { Inter-cell } \\
\text { movement } \\
\text { cost (\$) }\end{array}$ & $\begin{array}{c}\text { Intra-cell } \\
\text { movement } \\
\text { cost (\$) }\end{array}$ & $\begin{array}{c}\text { Total cell } \\
\text { configuration } \\
\text { cost (\$), } \mathbf{Z}_{\mathbf{w w}}\end{array}$ \\
\hline & & & & & \\
1 & 72,500 & 87,897 & 29,463 & 17,362 & 207,222 \\
2 & 67,755 & 71,635 & 27,125 & 14,136 & 180,651 \\
3 & 71,356 & 73,350 & 28,374 & 19,312 & 192,392 \\
\hline
\end{tabular}

Table 4: Solutions obtained for each product mix 


\begin{tabular}{|c|c|c|c|c|}
\hline \multirow{2}{*}{$\begin{array}{c}\text { Product mix, } \\
s\end{array}$} & $\begin{array}{c}\text { Probability, } \\
\pi_{s}\end{array}$ & \multicolumn{3}{|c|}{ Cost of cell configuration (\$) } \\
\cline { 3 - 5 } & $\mathrm{Z}_{1 \mathrm{w}}$ & $\mathrm{Z}_{2 \mathrm{w}}$ & $\mathrm{Z}_{3 \mathrm{w}}$ \\
\hline & & & & \\
2 & 0.4 & 207,222 & 199,229 & 195,592 \\
3 & 0.3 & 210,419 & 180,651 & 196,828 \\
& 0.3 & 212,887 & 189,326 & 192,392 \\
\hline
\end{tabular}

Table 5: Payoff matrix for different cell configuration

Now the weighted-average product mix is used to obtain the solution. Rosenblatt \& Kropp [30] initially proposed and used this concept of weighted-average product mix for solving the plant layout problem under stochastic conditions for a single-period. For the data set presented in Table 1, the weighted-average product mix using the relation $\bar{\Gamma}=\sum_{s=1}^{S} \Gamma_{s} \pi_{s}$ is determined for part types P1, P2...and P22 as 1800, 5550, 945, 1580, 4320, 885, 750, 8550, $675,2425,1625,1965,6800,7150,675,420,2850,3750,600,2600,1405$ and 1275 respectively. Then the solution is obtained using the weighted-average product mix. The total cost of the new cell configuration is $\$ 189,176$, which includes a machine constant cost of $\$ 71,225$, operating cost of $\$ 72,121$, inter-cell movement cost of $\$ 17,088$, and intra-cell movement cost of $\$ 28,742$. Table 6 compares the system design costs for using different cell configurations for different product mixes.

\begin{tabular}{|l|c|c|}
\hline \multicolumn{1}{|c|}{ Scenario } & Solution, $Z_{s}$ & Expected solution cost, $E\left[Z_{s}\right]$ \\
\hline Product mix 1 & $Z_{1}$ & $\$ 201,335$ \\
Product mix 2 & $Z_{2}$ & $\$ 197,411$ \\
Product mix 3 & $Z_{3}$ & $\$ 199,670$ \\
Weighted-average product mix & $Z$ & $\$ 189,176$ \\
\hline
\end{tabular}

Table 6: Costs comparison

It is evident that the cell configuration obtained for the weighted-average product mix results in a lower total cost, and so the corresponding cell configuration has been proposed for the launch of the new production unit. The proposed cell configuration comprises three cells. Cell 1 consists of machine types M2, M4, M5 (two units), M6, M9, M14, M15 and M16; part types P3, P6, P8, P11, P13, P14, P16 and P18 can be manufactured in this cell. Cell 2 consists of machine types $M 3$ (two units), M5, M6, M7 (two units), M8, M9, M12 and M15; part types P2, P5, P7, P8, P12, P19 and P22 can be made in this cell. Cell 3 consists of machine types M1, M7, M10, M11 (two units), M12, M13 and M16; part types P1, P4, P10, P12, P15, P17, P20 and P21 can be processed in this cell.

\section{CONCLUSION}

In this work, a genetic algorithm for a multi-objective integrated cell formation mathematical model to deal with the uncertainty of the product mix for a single period has been presented. The proposed solution model considered stochastic production requirements during the design stage itself. Also, a simultaneous consideration of various production parameters - such as alternate routing, operation sequence, duplicate machines, uncertain product mix, uncertain product demand, batch size, processing time, and machine capacity - has made the cell formation more complex but more realistic. The applicability of the proposed model is illustrated through the consultancy work carried out for the proposed auto-components manufacturing industry. It is evident from the case study problem that in an uncertain product mix environment, the cell configuration obtained using the weighted-average product mix approach results in a lower total cost than that of the expected cost approach proposed by Seiffoddini. The proposed model also has the advantage of simultaneously forming machine cells and part families. The algorithm was tested using problem data sets from the literature. The results suggest that the algorithm is 
efficient and provides near-optimal solutions in a reasonable time. This work can be extended to the mutli-period design CMSs under stochastic production requirements.

\section{REFERENCES}

[1] Wemmerlov, U. \& Johnson, D.J. 1997. Cellular manufacturing at 46 user plants: Implementation experiences and performance improvements, International Journal of Production Research, 35, pp. 29-49.

[2] Huber, V. \& Hyer, N. 1985. The human impact of cellular manufacturing, Journal of Operations Management, 4, pp. 183-195.

[3] Dale, B.G. 1999. Handbook of cellular manufacturing, John Wiley and Sons, USA.

[4] Wemmerlov, U. \& Hyer, N. 1986. Procedures for the part family/machine group identification problem in cellular manufacturing, Journal of Operations Management, 6, pp. 125-147.

[5] Kusiak, A. 1987. The generalized group technology concept, International Journal of Production Research, 25, pp. 561-569.

[6] Singh, N. 1993. Design of cellular manufacturing systems: An invited review, European Journal of Operations Research, 69, pp. 284-291.

[7] Reisman, A., Kumar, A., Motwai, J. \& Cheng, C. 1997. Cellular manufacturing: A statistical review of the literature (1965-1995), Operations Research, 45, pp. 508535.

[8] Selim, H., Askin, R.G. \& Vakharia, A.J. 1998. Cell formation in group technology: Review, evaluation and directions for future research, Computers and Industrial Engineering, 34, pp. 3-20.

[9] Sarkar, B. \& Mondal, S. 1999. Grouping efficiency measures in cellular manufacturing: A survey and critical review, International Journal of Production Research, 37, pp. 285-314.

[10] Mansouri, S.A., Moattar-Hussein, S.M. \& Newman, S.T. 2000. A review of the modern approaches to multi-criteria cell design, International Journal of Production Research, 38, pp. 1201-1218.

[11] Seifoddini, H. 1990. A probabilistic model for machine cell formation, Journal of Manufacturing Systems, 9, pp. 69-75.

[12] Sankaran, S. \& Kasilingam, R.G. 1993. On cell size and machine requirements planning in group technology systems, European Journal of Operations Research, 69, pp. 373-383.

[13] Harahalakis, G., Nagi, R. \& Proth, J. 1994. Manufacturing cell formation under random product demand, International Journal of Production Research, 32, pp. 4764.

[14] Chen, M. 1998. A mathematical programming model for systems reconfiguration in a dynamic cellular manufacturing environment, Annals of Operations Research, 77, pp. 109-128.

[15] Wicks, E.M. \& Resors, D.J. 1999. Designing cellular manufacturing systems with dynamic part populations, IIE Transactions, 31, pp. 11-20.

[16] Mungwatanna, A. 2000. Design of cellular manufacturing systems for dynamic and uncertain production requirement with presence of routing flexibility, $\mathrm{PhD}$ dissertation, Blacksburg State University, Virginia.

[17] Schaller, J. 2007. Designing and redesigning cellular manufacturing systems to handle demand changes, Computers and Industrial Engineering, 53, pp. 478-490.

[18] Chen, M. \& Cao, D. 2004. Coordinating production planning in cellular manufacturing environment using tabu search, Computers and Industrial Engineering, 46, pp. 571-582.

[19] Ioannou, G. 2006. Time-phased creation of hybrid manufacturing systems, International Journal of Production Economics, 102, pp. 183-198.

[20] Tavakkoli-Moghaddam, R., Aryanezhad, M.B., Safaei, N. \& Azaron, A. 2005. Solving a dynamic cell formation problem using metaheuristics, Applied Mathematics and Computation, 170, pp. 761-780. 
[21] Venugopal, V. \& Narendaran, T.T. 1992. A genetic algorithm approach to the machine-component grouping problem with multiple objectives, Computers and Industrial Engineering, 22, pp. 478-490.

[22] Gupta, Y.P., Gupta, M.C., Kumar, A. \& Sundram, C. 1996. A genetic algorithm based approach to cell composition and layout design problems, International Journal of Production Research, 34, pp. 625-641.

[23] Hu, G.H., Chen, Y.P., Zhou, Z.D. \& Fang, H.C. 2006. A genetic algorithm for the inter-cell layout and material handling system design, International Journal of Advanced Manufacturing_Technology, 34, pp. 1153-1163.

[24] Onwubolu, G.C. \& Mutingi, M. 2001. A genetic algorithm approach to cellular manufacturing systems, International Journal of Production Research, 32, pp. 185207.

[25] Suer, G.A., Vazquez, R. \& Cortes, M. 2005. A hybrid approach to genetic algorithms and local optimizers in cell loading, Computers and Industrial Engineering, 48, pp. 625-641.

[26] Tariq, A., Hussain, I. \& Ghafoor, A. 2008. A hybrid genetic algorithm for machinepart grouping, Computers and Industrial Engineering, 56, pp. 347-356.

[27] Holland, J.H. 1975. Adaptation in natural and artificial systems, University of Michigan Press, Ann Arbor, Ml.

[28] Goldberg, D.E. 1989. Genetic algorithms in search, optimization and machine learning, Addison-Wesley, Boston.

[29] Tavakkoli-Moghaddam, R., Safaei, N. \& Sassani, F. 2008. A new solution for a dynamic cell formation problem with alternative routing and machine costs using simulated annealing, Journal of Operations Research Society, 59, pp. 443-454.

[30] Rosenblatt, M. \& Kropp, D. 1992. The single period stochastic plant layout problem, IIE Transactions, 24, pp. 169-176. 